\title{
LITERASI KEUANGAN DAN KEPUASAN KEUANGAN DENGAN GENDER SEBAGAI MODERASI: STUDI PADA MAHASISWA DI KOTA PALEMBANG
}

\author{
Bunga Yulinar', Yuliani2, Rasyid HS Umrie ${ }^{3}$ \\ 1,2, 3 Fakultas Ekonomi, Universitas Sriwijaya \\ *Corresponding author email: yulianisyapril@unsri.ac.id
}

\begin{abstract}
ABSTRAK: Pengaruh literasi keuangan terhadap kepuasan keuangan dan menganalisis peran gender sebagai moderasi hubungan literasi keuangan dan kepuasan keuangan. Responden penelitian sebanyak 100 orang yang tersebar baik dari Perguruan Tinggi Negeri (PTN) dan Perguruan Tinggi Swasta (PTS) di Kota Palembang. Instrumen penelitian dengan menggunakan kuesioner. Pengumpulan data secara online dan ofline. Metode analisis data dengan Structural Equation Modeling (SEM). Penelitian ini menemukan bahwa terdapat pengaruh signifikan positif literasi keuangan terhadap kepuasan keuangan. Namun, gender bukan sebagai moderasi dalam hubungan literasi keuangan dan kepuasan keuangan. Teori tentang personal finance dalam konteks kepuasan keuangan masih perlu dieksplor kembali, mengingat perilaku setiap individu berbeda dikarenakan perbedaan latar belakang dan situasi saat pengambilan data penelitian.
\end{abstract}

Kata Kunci : literasi keuangan; gender; kepuasan keuangan

Abstract: The influence of financial literacy on financial satisfaction and analyzing gender roles as moderating the relationship between financial literacy and financial satisfaction. Research respondents were 100 people who were spread both from State Universities (PTN) and Private Universities (PTS) in Palembang City. The research instrument using a questionnaire. Online and offline data collection. Methods of data analysis using Structural Equation Modeling (SEM). This study found that there was a significant positive effect of financial literacy on financial satisfaction. However, gender is not a moderation in the relationship between financial literacy and financial satisfaction. The theory of personal finance in the context of financial satisfaction still needs to be explored again, considering that the behavior of each individual is different due to differences in backgrounds and situations when collecting research data.

Keywords: financial literacy; gender; financial satisfaction

\section{PENDAHULUAN}

Personal finance merupakan cabang ilmu keuangan yang berhubungan dengan manajemen keuangan pribadi, keluarga, dan perusahaan kecil. Literasi keuangan merupakan bentuk dari personal finance yang merupakan kebutuhan dasar yang harus dimiliki oleh individu agar terhindar dari masalah - masalah dalam keuangan (Laily, 2016). Literasi keuangan menurut (OJK, 2017) berarti pengetahuan, keterampilan, dan keyakinan, yang dapat mempengaruhi sikap dan perilaku sehingga dapat meningkatkan kualitas dalam pengambilan keputusan dan pengelolaan keuangan untuk mencapai kesejahteraan. 
Dalam survei nasional literasi dan inklusi tahun 2016 pada tahun 2013 menunjukkan tingkat literasi keuangan penduduk Indonesia sebesar 21,84\% kemudian pada tahun 2016 Ojk melakukan survey kembali dan tingkat literasi mengalami peningkatan yaitu menjadi 29,66\%. Dalam berita di Kompas.com pada tahun 2017 tingkat literasi menjadi 29,70\% dan meningkat menjadi 31\% pada tahun 2018.

Mahasiswa merupakan salah satu kelompok sasaran dalam peningkatan literasi keuangan dalam SNLIK dengan memberikan materi edukasi seputar lembaga jasa dan produk - produk keuangan, sehingga tingkat literasi keuangan pada pelajar atau mahasiswa sebesar 23,40\% dan ini menunjukkan bahwa masih rendahnya pengetahuan mahasiswa dalam keuangan.

Pengelolaan keuangan yang baik akan menciptakan perilaku yaitu kepuasan pada individu dalam hal keuangan. (Hadi \& Dewi, 2019) dalam penelitiannya menjelasakan bahwa kepuasan keuangan merupakan sudut pandang subjektif yang dirasakan oleh individu dari ketersediannya sumber daya keuangan yang dimiliki.

Terdapat research gap dalam penelitian literasi keuangan pada variabel kepuasan keuangan yang menunjukkan adanya pengaruh literasi keuangan pada kepuasan keuangan sehingga peneliti ingin menambahkan variabel ketiga yaitu gender sebagai variabel moderasi. Sehingga dengan merujuk gender sebagai variabel moderasi peneliti dapat melihat pengaruh antara perbedaan gender pada hubungan literasi keuangan terhadap kepuasan keuangan. Perbedaan gender akan mengacu kepada status legal, sosial dan individual seseorang sebagai laki - laki atau perempuan atas dasar kriteria perilaku dan fisik, Perbedaan gender juga akan terlihat pada sifat dan perilaku (Utaminingsih \& Rita, 2010).

Penelitian yang dilakukan oleh (Hasibuan et al., 2018) menjelaskan bahwa literasi keuangan berpengaruh positif terhadap kepuasan keuangan. Penelitian tersebut didukung oleh penelitian yang dilakukan oleh (Falahati et al., 2012) bahwa literasi keuangan dapat memprediksi kepuasan keuangan (financial satisfaction).

Perbedaan gender dalam pengelolaan keuangan pribadi menyebabkan perbedaan kepuasan keuangan yang dirasakan seseorang (Sina, 2013). Sedangkan penelitian yang dilakukan (Sahi et al., 2016) menjelaskan bahwa tidak ada hubungan yang signifikan antara gender dan kepuasan keuangan. Menurut (Herlindawati, 2014) dalam penelitiannya menjelaskan bahwa jenis kelamin tidak berpengaruh terhadap pengelolaan keuangan pribadi mahasiswa.

\section{METODE PENELITIAN}

Ruang lingkup dalam penelitian ini yaitu literasi keuangan sebagai variabel independen terhadap kepuasan keuangan sebagai variabel dependen dan gender sebagai variabel moderasi pada mahasiswa di Kota Palembang. 
Rancangan penelitian dalam penelitian ini yaitu jenis penelitian kuantitatif yaitu yang berasal dari scoring dari presepsi responden mengenai literasi keuangan dan kepuasan keuangan mahasiswa di Kota Palembang.

Jenis data yang digunakan pada penelitian ini adalah data kuantitatif yang berasal dari angka atau scoring dari presepsi responden mengenai literasi keuangan dan kepuasan keuangan. Sumber data yang digunakan dalam penelitian terdiri dari data primer yang diperoleh dengan memberikan kuesioner, secara langsung dan penyebaran kuesioner secara online kepada responden penelitian yaitu mahasiswa di Kota Palembang. Data sekunder diperoleh dengan cara studi pustaka dari referensi berupa buku, jurnal, artikel, internet, peraturan perundang - undang.

\section{HASIL DAN PEMBAHASAN}

\section{Uji Validitas Instrument Penelitian}

Pengujian validitas ini di lakukan dengan menggunakan Correlation Matrix yaitu dengan membandingkan nilai $\mathrm{r}_{\text {hitung }}$ (Correlation Item - Total Correlation) pada tarif signifikan yang di tentukan dengan $r_{\text {tabel }}$ pada taraf signifikan 5\% adalah 0,1966 (n-2 = 100-2 =98). Jika nilai $r_{\text {hitung }}$ lebih besar dari nilai $r_{\text {tabel }}\left(r_{\text {hitung }}>0,1966\right)$, maka ini berarti butir butir item soal pernyataan dinyatakan valid (diterima) dan memenuhi syarat sebagai alat ukur (sujarweni, 2015). Variabel penelitian yaitu literasi Keuangan $\left(\mathrm{X}_{1}\right)$ dan Kepuasan Keuangan $(\mathrm{Y})$ seperti tabel berikut ini:

Tabel 1

Hasil Uji Validitas Butir Instrument Variabel Penelitian

\begin{tabular}{|c|c|c|c|c|}
\hline & Nomor Pernyataan & $r_{\text {hitung }}$ & $\mathbf{r}_{\text {tabel }}$ & Keterangan \\
\hline \multirow{8}{*}{$\begin{array}{l}\text { Literasi } \\
\text { Keuangan } \\
\left(\mathrm{X}_{1}\right)\end{array}$} & $\begin{array}{l}\text { Dapat terhindar dari segala bentuk } \\
\text { penipuan. }\end{array}$ & 0,541 & 0,1966 & Valid \\
\hline & $\begin{array}{l}\text { Nilai uang sekarang sama nilainya } \\
\text { dengan uang } 5 \text { tahun mendatang. }\end{array}$ & 0,507 & 0,1966 & Valid \\
\hline & $\begin{array}{l}\text { Membuat dan mengelola anggaran } \\
\text { untuk } 1 \text { bulan. }\end{array}$ & 0,401 & 0,1966 & Valid \\
\hline & $\begin{array}{l}\text { Memperioritaskan penggunaan } \\
\text { uang. }\end{array}$ & 0,530 & 0,1966 & Valid \\
\hline & $\begin{array}{llr}\text { Menyisihkan } & \text { uang dapat } \\
\text { membuat saya terhindar dari } \\
\text { hutang. }\end{array}$ & 0,386 & 0,1966 & Valid \\
\hline & $\begin{array}{l}\text { Tabungan adalah cara pemenuhan } \\
\text { kebutuhan konsumsi. }\end{array}$ & 0,475 & 0,1966 & Valid \\
\hline & $\begin{array}{l}\text { Menyimpan uang yang aman di } \\
\text { bank. }\end{array}$ & 0,574 & 0,1966 & Valid \\
\hline & Menanggulangi resiko dengan & 0,584 & 0,1966 & Valid \\
\hline
\end{tabular}




\begin{tabular}{|c|c|c|c|c|}
\hline \multirow[t]{4}{*}{ Variabel } & Nomor Pernyataan & $\mathbf{r}_{\text {hitung }}$ & $\mathbf{r}_{\text {tabel }}$ & Keterangan \\
\hline & asuransi. & & & \\
\hline & $\begin{array}{l}\text { Bentuk perencanaan jangka } \\
\text { panjang yaitu investasi. }\end{array}$ & 0,571 & 0,1966 & Valid \\
\hline & $\begin{array}{l}\text { Emas merupakan bentuk investasi } \\
\text { yang paling aman. }\end{array}$ & 0,559 & 0,1966 & Valid \\
\hline \multirow{10}{*}{$\begin{array}{l}\text { Kepuasan } \\
\text { Keuangan } \\
\text { (y) }\end{array}$} & $\begin{array}{l}\text { Puas membeli barang yang } \\
\text { diinginkan. }\end{array}$ & 0,596 & 0,1966 & Valid \\
\hline & $\begin{array}{l}\text { Puas dengan kondisi keuangan } \\
\text { sekarang. }\end{array}$ & 0,622 & 0,1966 & Valid \\
\hline & Puas membeli kebutuhan kuliah. & 0,694 & 0,1966 & Valid \\
\hline & $\begin{array}{l}\text { Puas membeli buku pedoman } \\
\text { kuliah. }\end{array}$ & 0,656 & 0,1966 & Valid \\
\hline & $\begin{array}{l}\text { Puas uang saku cukup untuk } \\
\text { kebutuhan } 1 \text { bulan. }\end{array}$ & 0,575 & 0,1966 & Valid \\
\hline & Puas dapat membuat anggaran. & 0,665 & 0,1966 & Valid \\
\hline & $\begin{array}{l}\text { Puas penggunaan anggaran yang } \\
\text { sesuai. }\end{array}$ & 0,700 & 0,1966 & Valid \\
\hline & $\begin{array}{l}\text { Puas dapat terhindar dari masalah } \\
\text { kredit. }\end{array}$ & 0,740 & 0,1966 & Valid \\
\hline & $\begin{array}{l}\text { Puas terhindar dari situasi } \\
\text { mendesak. }\end{array}$ & 0,588 & 0,1966 & Valid \\
\hline & $\begin{array}{l}\text { Puas pengetahuan tentang Logam } \\
\text { Mulia merupakan investasi. }\end{array}$ & 0,547 & 0,1966 & Valid \\
\hline
\end{tabular}

Sumber: Data Primer yang diolah SPSS Versi 23

\section{Uji Reabilitas}

Uji realibilitas di lakukan untuk mengetahui ukuran suatu kestabilan dan konsistensi dalam menjawab butir - butir pada setiap pernyataan di kuesioner. Dalam penelitian ini untuk melihat reliable atau tidaknya yaitu apabila nilai Reliability Coefficient (Alpha) nilainya > 0,60 maka variabel dan butir pernyataan dinyatakan reliable. Seperti pengolahan data berikut ini

Tabel 2

Hasil Uji Realibilitas Instrument Variabel Penelitian

\begin{tabular}{ccc}
\hline Variabel & Cronbach's Alpha & Keterangan \\
\hline Literasi Keuangan & 0,717 & Reliable \\
Kepuasan Keuangan & 0,755 & Reliable \\
\hline
\end{tabular}

Sumber: Data Primer yang diolah SPSS Versi 23

Berdasarkan hasil Uji Realibilitas pada Tabel 1 diatas diketahui bahwa nilai cronbach's Alpha baik pada variabel Literasi Keuangan ( $\left.\mathrm{X}_{1}\right)$ dan variabel Kepuasan Keuangan (Y) menunjukkan berada di atas 0,60 (Cronbah's Alpha > 0,60). 


\section{Uji Asumsi Klasik}

a. Uji Autokorelasi

Uji autokorelasi di lakukan untuk mengetahui ada tidaknya korelasi antara variabel pengganggu pada periode tertentu dengan variabel berikutnya. Uji autokorelasi dilakukan dengan melihat nilai Durbin Watson dan dibandingkan dengan tabel Durbin Watson $(d l$ dan $d u$ ). Dengan kriteria jika $d u<d$ hitung $<4-d u$ maka tidak terjadi autokorelasi (Sujarweni, 2015).

Berdasarkan hasil uji autokorelasi pada tabel 4.13 menunjukan bahwa nilai Durbin-Watson sebesar 1,933 atau jika melihat dari kriteria $d u<\mathrm{d}$ hitung $<4-d u$ maka nilainya 1,6944 < 1,933< 2,3056 yang artinya menunjukan tidak terjadinya autokorelasi.

\section{b. Uji Multiolinieritas}

Uji multikolinieritas di lakukan untuk mengetahui ada tidaknya variabel independen yang memiliki kemiripan antar variabel independen dalam suatu model dengan melihat dari nilai VIF 1 - 10 maka tidak terjadi Multikolinieritas.

Berdasarkan uji multikolinieritas menunjukan nilai VIF variabel literasi keuangan dan gender sebesar 1,002 yang berarti nilainya kurang dari 10 atau berada diantara 1 - 10 dan nilai tolerance $>0,10$ maka dapat disimpulkan bahwa data literasi keuangan dan gender dapat dikatakan tidak terjadi multikolinieritas.

\section{c. Uji Heteroskedastisitas}

Uji heteroskedastisitas di lakukan untuk melihat terjadinya perbedaan varians residual suatu periode pengamatan ke periode pengamatan yang lain. Cara memprediksinya yaitu menggunakan uji glejser yang meregres nilai absolud residual terhadap variabel bebas (Sujarweni, 2015).

Berdasarkan hasil uji glejser pada tabel 4.15 menunjukan bahwa nilai signifikansi (sig.) pada variabel literasi keuangan $>0,05$ yaitu 0,581 dan variabel gender $>0,05$ yaitu 0,611 maka dapat disimpulkan tidak terjadi heteroskedastisitas pada variabel literasi keuangan.

\section{Analisis Regresi Dengan Variabel Moderasi}

Analisis regresi dengan variabel moderasi digunakan untuk mengetahui apakah variabel independen yang akan memperkuat atau melemahkan hubungan diantara variabel dependen dan independen. Regresi dengan variabel moderasi menggunakan 2 model regresi yaitu regresi linier sederhana dan regresi linier berganda. 
1.) Analisis Regresi Linier Sederhana

Tabel 3

Analisis Persamaan Regresi Linier Sederhana

\begin{tabular}{llc}
\hline Model & \multicolumn{1}{c}{ Variabel } & Unstandardized Coefficients B \\
\cline { 3 - 3 } 1 & (Constant) & 12.921 \\
& Literasi Keuangan & 0.677 \\
\hline
\end{tabular}

Sumber: Data Primer yang diolah SPSS Versi 23

Persamaan Regresi sebagai berikut :

$$
\mathrm{Y}=12,921+0,667 \mathrm{LK}+\mathrm{e}
$$

Persamaan regresi linier sederhana ini dapat diartikan sebagai berikut:

1. Constant $(\mathrm{a})=12,921$

Nilai constant (a) adalah sebesar 12,921. Artinya apabila literasi keuangan sama dengan nol, maka nilai kepuasan keuangan Mahasiswa di Kota Palembang yaitu sebesar 12,921.

2. Koefisien Regresi

Hal tersebut menyatakan bahwa setiap penambahan 1 satuan nilai literasi keuangan, maka nilai kepuasan keuangan sebesar 0,667. Koefisien regresi tersebut bernilai positif, sehingga dapat dikatakan bahwa arah pengaruh variabel literasi keuangan terhadap kepuasan keuangan adalah positif, atau dapat dikatakan jika variabel literasi keuangan $\left(X_{1}\right)$ ditingkatkan maka kepuasan keuangan akan bertambah sebesar 0,667.

\section{Analisis Regresi Berganda}

Tabel 4

Hasil Analisis Regresi Linier Berganda

\begin{tabular}{cccc}
\hline Model & Variabel & Unstandardized Coefficients B \\
\hline \multirow{3}{*}{1} & (Constant) & 6.046 \\
\cline { 2 - 4 } & Literasi Keuangan & .833 \\
\cline { 2 - 4 } & Gender & 4.419 & \\
\cline { 2 - 3 } & Literasi Keuangan*Gender & -.100 \\
\hline \multicolumn{4}{c}{ Sumber : Data Primer yang diolah SPSS 23 }
\end{tabular}

Persamaan Regresi sebagai berikut :

$$
\mathrm{Y}=6,046+0,833 \mathrm{LK}+4,419 \mathrm{G}+\left(-100 \mathrm{LK}^{*} \mathrm{G}\right)+\mathrm{e}
$$


Persamaan regresi linier sederhana ini dapat diartikan sebagai berikut :

1. Constant (a) $=6,046$

Nilai constant (a) adalah sebesar 6,046. Hal ini menyatakan jika kepuasan keuangan, literasi keuangan, dan interaksi literasi keuangan dengan gender pada Mahasiswa di Kota Palembang sebesar 6,046.

2. Koefisien Regresi

a. Koefisien Literasi Keuangan =0,833

Hal tersebut menjelaskan bahwa setiap penambahan 1 nilai literasi keuangan, maka nilai kepuasan keuangan bertambah 0,833.

b. Koefisien Gender = 4,419

Hal tersebut menjelaskan bahwa setiap penambahan 1 nilai gender, maka kepuasan keuangan bertambah 4,419.

c. Koefisien Literasi Keuangan * Gender $=-100$

Hal tersebut menjelaskan bahwa setiap terjadi perubahan literasikeuangan oleh gender sebesar 1 nilai maka kepuasan keuangan akan mengalami perubahan sebesar -100 .

\section{Hasil Uji Hipotesis (Uji t Parsial)}

Uji $t$ (parsial) digunakan untuk melihat tingkat signifikansi hubungan antara variabel $\mathrm{X}$ dan $\mathrm{Y}$, apakah variabel literasi keuangan $\left(X_{1}\right)$, kepuasan keuangan $(Y)$. Jika nilai $t_{\text {hitung }}>t_{a b e l}$, maka literasi keuangan memiliki pengaruh signifikan terhadap kepuasan keuangan. Sedangkan jika nilai $t_{\text {hitung }}<t_{\text {tabel }}$ hal ini berarti literasi keuangan tidak memiliki pengaruh signifikan terhadap kepuasan keuangan. Begitupun jika tingkat signifikan < 0,05 maka literasi keuangan memiliki pengaruh signifikan terhadap kepuasan keuangan dan jika nilai signifikan $>0,05$ maka literasi keuangan tidak memiliki pengaruh yang signifikan terhadap kepuasan keuangan.

Tabel 5

Hasil Analisis Uji t

\begin{tabular}{cccc}
\hline \multirow{2}{*}{ Model } & Variabel & $\mathbf{T}$ & Sig. \\
\hline \multirow{2}{*}{1} & (Constant) & 3.588 & .001 \\
\cline { 2 - 4 } & Literasi Keuangan & 7.633 & .000 \\
\hline \multicolumn{4}{c}{ Sumber : Data Primer yang diolah SPSS Versi 23}
\end{tabular}

Berdasarkan penjelasan sebelumnya diketahui bahwa nilai koefisien regresi variabel literasi keuangan yaitu sebesar 0,667 dan bernilai positif. Selanjutnya pada tabel 4.18 memberikan informasi diatas diperoleh nilai $t_{\text {hitung yaitu }}$ sebesar $(7,633)>t_{\text {tabel }}(1,98387)$, dengan tingkat signifikan sebesar 0,000 lebih kecil dari 0,05 $(0,000<$ $0,05)$. Berdasarkan penjelasan di atas dapat diartikan bahwa variabel literasi keuangan terdapat pengaruh positif dan signifikan terhadap variabel kepuasan keuangan pada mahasiswa di Kota Palembang sehingga hipotesis pertama diterima. 
Hal ini sesuai dengan theory of planned behaviori dalam penelitian (Safitri \& Sukirman, 2018) yang menjelaskan bahwa perilaku manusia bisa disebabkan oleh alasan - alasan atau kemungkinan yang berbeda. Dalam penelitian ini alasan - alasan atau kemungkinan yang menimbulkan suatu perilaku dari dalam diri individu yaitu pengetahuan, keterampilan, dan keyakinan yang merupakan pengertian dari literasi keuangan dan perilaku yang ditimbulkan oleh individu yaitu kepuasan keuangan individu terhadap kondisi keuangannya.

Hasil penelitian (Hasibuan et al., 2018) menyatakan bahwa pengetahuan keuangan pribadi atau literasi keuangan itu penting untuk menghindari terjadinya kesalahpahaman dalam membuat keputusan keuangan dengan benar dan mencapai kesejahteraan dalam hal keuangan, jika keputusan keuangan dibuat dengan baik maka akan mencapai kepuasan keuangan, sehingga penelitian ini menyatakan literasi keuangan berpengaruh positif terhadap kepuasan keuangan. Hasil penelitian ini juga didukung oleh penelitian yang dilakukan (Xiao et al., 2014) yang menyatakan bahwa pengetahuan keuangan berpengaruh positif terhadap kepuasan keuangan. Penelitian terdahulu yang dilakukan (Falahati et al., 2012) juga menyatakan bahwa sikap keuangan, perilaku keuangan, dan literasi keuangan dapat memprediksi kepuasan keuangan (financial satisfaction).

Tabel 6

Hasil Analisis Uji t Setelah Di Moderasi Oleh Gender

\begin{tabular}{|c|c|c|c|}
\hline Model & Variabel & $\mathbf{T}$ & Sig. \\
\hline \multirow[t]{4}{*}{1} & (Constant) & .513 & .609 \\
\hline & Literasi Keuangan & 2.879 & .005 \\
\hline & Gender & .607 & .546 \\
\hline & Literasi Keuangan*Gender & -.559 & .577 \\
\hline
\end{tabular}

Sumber : Data Primer yang diolah SPSS Versi 23

Berdasarkan penjelasan sebelumnya memberikan informasi pengaruh literasi keuangan dengan gender sebagai variabel moderasi menunjukan hasil regresi gender menunjukkan nilai $t_{\text {hitung }} 0,607<t_{\text {tabel }}$ $(1,98387)$ dengan nilai signifikan sebesar 0,546 yaitu lebih besar dari 0,05 $(0,546>0,05)$ ini menunjukkan bahwa gender bukanlah variabel moderasi. Sedangkan hasil regresi literasi keuangan dengan gender berpengaruh negative terhadap kepuasan keuangan dengan nilai $t_{\text {hitung }}-0,559<t_{\text {tabel }}$ $(1,98397)$ dengan tingkat signifikan sebesar 0,577 lebih besar dari 0,05 $(0,557>0,05)$. Sehingga dapat diartikan bahwa gender bukan variabel moderasi antara hubungan variabel literasi keuangan terhadap kepuasan keuangan pada Mahasiswa di Kota Palembang sehingga hipotesis kedua ditolak. 
Theory of planned behavior menunjukkan bahwa latar belakang seperti jenis kelamin, usia, indeks prestasi kumulatif, pendapatan orang tua, dan personal financial awareness mempengaruhi keyakinan seseorang terhadap sesuatu yang pada akhirnya akan mempengaruhi perilaku seseorang. Namun, dalam penelitian ini theory of planned behavior tidak mendukung jenis kelamin sebagai salah satu factor yang mempengaruhi perilaku seseorang dengan pembuktian bahwa gender bukan sebagai variabel moderasi literasi keuangan terhadap kepuasan keuangan.

Hasil penelitian ini juga mendukung penelitian yang dilakukan oleh (Sahi et al., 2016) menunjukkan bahwa tidak ada hubungan yang signifikan antara gender dan kepuasan keuangan. Dalam penelitian terdahulu yang dilakukan oleh (Herlindawati, 2014) menjelaskan bahwa jenis kelamin tidak berpengaruh atau tidak mampu membedakan sikap baik atau buruk individu terhadap pengelolaan keuangan pribadi mahasiswa yang terlihat dari perilaku individu yang tidak mampu membedakan sikap terhadap uang sehingga perempuan belum tentu memiliki kemampuan pengelolaan keuangan yang tinggi ataupun sebaliknya bahwa laki-laki juga belum tentu mempunyai kemampuan dalam pengelolaan keuangan yang rendah.

\section{KESIMPULAN}

Berdasarkan hasil penelitain yang melihat peran gender sebagai moderasi variabel literasi keuangan terhadap variabel kepuasan keuangan pada Mahasiswa di Kota Palembang. Dalam penelitian ini dapat disimpulkan bahwa:

a. Literasi keuangan berpengaruh secara positif dan signifikan terhadap kepuasan keuangan pada Mahasiswa di Kota Palembang.

b. Gender tidak signifikan maka gender bukan sebagai variabel moderasi literasi keuangan terhadap kepuasan keuangan pada Mahasiswa di Kota Palembang.

\section{SARAN}

Berdasarkan hasil penelitian yang diperoleh, maka saran dari peneliti adalah sebagai berikut:

1. Bagi mahasiswa.

Sebagai mahasiswa yang memiliki ilmu pengtahuan dari perguruan tinggi masing - masing seharusnya mengaplikasikan ilmu yang telah didapat sehingga menjadi individu yang kritis dan cerdas dalam mengelola keuangan dengan produk - produk keuangan yang telah ada seperti bank, asuransi, investasi.

2. Bagi peneliti selanjutnya.

Diharapkan penelitian ini dapat menjadi bahan referensi atau literature penelitian lebih lanjut yang berhubungan dengan gender sebagai moderasi literasi keuangan terhadap kepuasan keuangan dan diharapkan dapat lebih luas dan menemukan variabel lain yang dapat 
mempengaruhi kepuasan keuangan seperti perilaku keuangan, sikap keuangan. Selain itu juga dapat memperluas variabel moderasi seperti umur dan tingkat pendidikan, hal ini dimaksudkan agar tercipta temuan baru.

\section{UCAPAN TERIMAKASIH}

Ucapan terima kasih penulis sampaikan kepada seluruh narasumber yang bersedia membantu dan memberikan informasi yang diperlukan pada penelitian ini. Ucapan terima kasih juga kami sampaikan kepada para pihak yang membantu dalam selesainya tulisan ini.

\section{REFERENSI}

Falahati, L., Sabri, M. F., \& Paim, L. H. J. (2012). Assessment a model of financial satisfaction predictors: Examining the mediate effect of financial behaviour and financial strain. World Applied Sciences Journal, 20(2), 190-197.

Hadi, H. D. K., \& Dewi, A. S. (2019). Peran Kemampuan Keuangan Sebagai Mediator Pendidikan Keuangan Dan Kepuasan Keuangan (Studi Kasus Pada Usia Produktif Di Kota Surabaya). Jurnal Wawasan Dan Riset Akuntansi, 6(2), 74-88.

Hasibuan, B. K., Lubis, Y. M., \& HR, W. A. (2018). Financial Literacy and Financial Behavior as a Measure of Financial Satisfaction. July.

Herlindawati, D. (2014). Pengaruh Kontrol Diri, Jenis Kelamin, dan Pendapatan Terhadap Pengelolaan Keuangan Pribadi Mahasiswa Pascasarjana Universitas Negeri Surabaya. 158-169.

Laily, N. (2016). Pengaruh literasi keuangan terhadap perilaku mahasiswa dalam mengelola keuangan. Journal of Accounting and Business Education, 1(4), 1-17.

OJK. (2017). Strategi Nasional Literasi Keuangan Indonesia (Revisit 2017). 199.

Safitri, N. A., \& Sukirman. (2018). Analisis Faktor - Faktor Yang Mempengaruhi Financial Behavior. 2(1), 18-23.

Sahi, A., Lai, D., \& Li, Y. (2016). Security and privacy preserving approaches in the eHealth clouds with disaster recovery plan. Computers in Biology and Medicine, 78, 1-8.

Shalini Kalra Sahi. (2016). Demographic and socio-economic determinants of financial satisfaction. Finance, FORE School of Management, New 
Delhi, India.

Sina, P. G. (2013). Financial efficacy dan financial satisfaction: ditinjau dari perbedaan gender. Jurnal Manajemen Maranatha, 12(2).

Sujarweni, V. W. (2015). Metodologi penelitian bisnis dan ekonomi.

Utaminingsih, R., \& Rita, M. R. (2010). Financial Attitudes Dan Komunikasi Keluarga Tentang Pengeluaran Uang Saku: Ditinjau Dari Perbedaan Gender. Jurnal Manajemen Dan Keuangan, 8(2), 206-219.

Xiao, J. J., Chen, C., \& Chen, F. (2014). Consumer financial capability and financial satisfaction. Social Indicators Research, 118(1), 415-432. 